\title{
A New Spectrophometric Method For The Analysis Of Fructose, Glucose And Sucrose, Using 2-Thiobarbituric Acid And Zero-Valent Iron Powder (ZVIP)
}

\author{
Karine Assaker ${ }^{1} \&$ Jamil Rima $^{2}$ \\ ${ }^{1}$ Platform of Research and Analysis in Environmental Sciences, PRASE, Doctoral School for Sciences and \\ Technologies, Hadath Campus, Lebanese University, Lebanon \\ ${ }^{2}$ Laboratory of Physical chemistry and Environmental Engineering, Faculty of Science II., Lebanese University, \\ Fanar, P.Q. BOX 26110217 Fanar Matn, Lebanon \\ Correspondence: Jamil Rima, Laboratory of Physical chemistry and Environmental Engineering, Faculty of \\ Science II. Lebanese University Fanar, P.Q. BOX 26110217 Fanar Matn, Lebanon. Tel: 961-332-1833. E-mail: \\ jrima@ul.edu.lb
}

Received: December 28, 2018

Accepted: January 24, 2019

Online Published: February 18, 2019

doi:10.5539/jfr.v8n2p48

URL: https://doi.org/10.5539/jfr.v8n2p48

\begin{abstract}
A new spectrophotometric method has been developed for the determination of fructose, glucose and sucrose in fruit juices. The method is based on the oxidation of sugars with zero valent iron powder in acidic $\mathrm{pH}$ aqueous solution and bubbled with air. Oxidized by-products were complexed with 2-thiobarbituric and monitored by UV-Vis spectroscopy. The recorded spectra are specifically characteristic for fructose, glucose and sucrose respectively. Calibration curves were studied for each compound and the quantitative determination of carbohydrate concentrations was carried out using an internal standard addition method. The average relative standard deviation is $4 \%$ and recovery rate range from $98 \%$ to $103 \%$ for spiked concentrations of $0.05-4 \mathrm{mM}$ carbohydrates. The detection limit are 13, 15 and $12 \mu \mathrm{M}$ for fructose, glucose and sucrose respectively. The oxidation of carbohydrates gives rise to certain by-products, presents a new method of indirect measurement of carbohydrates. This method is applied in the determination of carbohydrates in juices and other foods in a precise, easy and inexpensive way.
\end{abstract}

Keywords: oxidized by-products, carbohydrates, juices, analysis, and spectrophotometric method

\section{Introduction}

The determination of individual sugar content in fresh fruits and vegetables and their juices is an important chemical analysis carried out to evaluate quality and to detect adulteration or contaminants. Analytical techniques such as high performance liquid chromatography (HPLC) using different separation mechanisms (adsorption, size exclusion, or ion exchange) and various detectors (refractive index, UV absorption, amperometric, etc.), thin-layer chromatography (TLC), and gas chromatography (GC) have been commonly used for qualitative and quantitative analyses of fruit juices (Stober et al., 1998; Arias et al., 2003; Weiß 2017). While chromatographic techniques are very accurate, they are time-consuming and require tedious sample preparations. Sugar analyses carried out by enzymatic assays are specific, rapid and reproducible (Whitesides 1984; Matsumoto et al., 1990). However, the analyses require single determinations for each compound, which results in time-consuming procedures and high cost of analysis (Trifirò et al., 1997; Vodnar and Socaciu 2008). Lanza and $\mathrm{Li}$ (Lanza Li,B.W. 1984), Li et al. (Li et al., 1996) and Lorimor et al. (Ye et al., 2005) reported the application of Near Infrared (NIR) spectroscopy for the direct analysis of total sugar content in fruit juices (Suhandy et al., 2012). However, they concluded that it was not possible to determine individual sugars with acceptable accuracy or precision by using the transmission mode with a quartz cell path length of $2.2 \mathrm{~mm}$. Giangiacomo and Dull (Giangiacomo and Dull 1986) and Ze'ev Schmilovitch et al. (Schmilovitch et al., 2000) developed NIR models based on transmittance measurements that predicted individual sugars (sucrose, glucose, and fructose) in aqueous mixtures with a standard error of prediction of 0.35-0.69. Improved sensitivity and accuracy for the quantitative analysis of individual sugars in juices have been accomplished by placing the liquid sample on a fiberglass support, eliminating the water and measuring the dry extract by diffuse reflectance 
spectroscopy (Alfaro et al., 1990; Li et al., 1996). Advances in Fourier transform NIR (FT-NIR) spectroscopic instrumentation and multivariate data analysis techniques have had significant impact in the determination of changes in food composition. FT-NIR improves spectra reproducibility and wave number precision (McClure 1994; Schmutzler et al., 2015) which can minimize the effects of solvent interference. However, the analysis of individual sugars by the techniques cited above are either very expensive or need extensive expertise or sophisticated instrumentation.

A fluorimetric method has been used to analyze fructose, glucose and sucrose (Danielson et al., 1999). This method is based on the reaction between zirconyl chloride and the carbohydrates to form a fluorescent derivative. The LODs were below $1 \mu \mathrm{g}$. However, to our knowledge there is no spectrophotometric procedure based on the oxidation between the carbohydrates and zero valent iron powder followed by the 2-thiobarbituric acid test. The objective of this work was to develop a new, economical and simple procedure for the determination of fructose, glucose and sucrose in the fruit juices.

We demonstrated scavenging of the hydroxyl free radicals derived from oxidation reaction between ZVIP and sugars, which, giving rise to a specific by-product characterized by its reaction with thiobarbutiric acid. We used such series of reactions to develop a new methodology for the rapid identification and quantification of individual sugars in fruit juices.

\section{Materials and Methods}

\subsection{Reagents}

All reagents were of analytical grade $99.7 \%$ purities. Sucrose, glucose, fructose, glacial, acetic acid and sodium acetate trihydrate, Butyl rubber stopper, were purchased from Sigma Chemical Co. (St. Louis, MO, USA). 2-Thiobarbituric acid (TBA) was obtained from Fluka AG (Buchs, Switzerland), and zero-valent iron powder (ZVIP) (325 mesh) was obtained from Merck (Darmstadt, Germany). Double-distilled water was deionized with Milli-Q water purification system (Millipore) and filtered by a Millipak 40 cartridge $(0.22$ $\mu . \mathrm{m})$ before use.

\subsection{Instruments}

A Shimadzu UV-VIS 1650 PC spectrophotometer was used to record the absorption spectra. The $\mathrm{pH}$ values were measured with a WTW $\mathrm{pH} / \mathrm{mV}$ Hand-Held meter 330/SET. The $\mathrm{pH}$ meter was calibrated with standard buffer solutions.

\subsection{Preparation of Acetate Buffer Solution}

$1.5 \mathrm{ml}$ of glacial acetic acid is added to $100 \mathrm{ml}$ with distilled water. $0.64 \mathrm{~g}$ of sodium acetate or $2.72 \mathrm{~g}$ of sodium acetate trihydrate are dissolved in $100 \mathrm{ml}$ of distilled water.

Pipette out exactly $36.2 \mathrm{ml}$ of sodium acetate solution into $100 \mathrm{ml}$ of standard flask and add $14.8 \mathrm{ml}$ of glacial acetic acid, make the volume $100 \mathrm{ml}$ using distilled water using distilled water. This gives $0.2 \mathrm{M}$ of acetic acid and sodium acetate buffer solution with $\mathrm{pH}=4.6$

\subsection{Standard Solution}

All experiments were carried out at room temperature $\left(22 \pm 1^{\circ} \mathrm{C}\right)$ in acetate buffer $(0.2 \mathrm{M} \mathrm{pH} 4.6)$. The ZVIP was treated with $200 \mathrm{~mL}$ of $1 \mathrm{M} \mathrm{HCl}$ for $10 \mathrm{~min}$, and then washed with deionized water four times to remove all residual $\mathrm{HCl}$ and $\mathrm{Fe}$. The carbohydrate stock solutions were $15 \mathrm{mM}$. The working solutions of carbohydrates were made with appropriate dilution. $10 \mathrm{ml}$ of carbohydrate stock solution $(15 \mathrm{mM})$ were mixed with $20 \mathrm{~mL}$ of acidified deionized water $(\mathrm{pH}=4.6)$ and transferred into a flask of $100 \mathrm{~mL} .0 .5 \mathrm{~g}$ of zero valent iron powder were also added into the flask and shaken for 10 minutes. For analysis, $3 \mathrm{ml}$ of the solution, treated with ZVIP, was added to $3 \mathrm{ml}$ of TBA in $15 \%$ acetic acid (1\% TBA, w/v). The mixture was heated in a water bath maintained at $100{ }^{\circ} \mathrm{C}$ for 15 minutes. After the mixture was cooled, the absorption spectrum of the mixture was measured. Table 1 summarizes the experimental data of samples of sugars in mixtures and the preparation method of the internal standard addition procedure. 
Table 1. Experimental data of sugars in mixtures ${ }^{\mathrm{a}}$

\begin{tabular}{lllllll}
\hline Replicate & & \multicolumn{5}{c}{ Concentration $(\mathrm{mM})$} \\
\cline { 2 - 7 } & Fructose & Glucose & Sucrose & $\begin{array}{l}\text { Volume of water } \\
\text { added }(\mathrm{ml})\end{array}$ & $\begin{array}{l}\text { Level of } \\
\text { fortification } \mathrm{mM}\end{array}$ & $\begin{array}{l}\text { Total volume of } \\
\text { the sample mL }\end{array}$ \\
\hline 1 & 1 & 1 & $\mathrm{Q}_{0}{ }^{\mathrm{b}}$ & 3 & 0 & 5 \\
2 & 1 & 1 & 0.5 & 2.5 & 0.5 & 5 \\
3 & 1 & 1 & 1 & 2 & 1 & 5 \\
4 & 1 & 1 & 1.5 & 1.5 & 1.5 & 5 \\
5 & 1 & 1 & 2 & 1 & 2 & 5 \\
\hline
\end{tabular}

${ }^{a}$ Concentration of sucrose to be found $\left(\mathrm{Q}_{0}\right)$. ${ }^{\mathrm{b}}$ No sugar control.

\subsection{Sample Preparations}

Fruit samples were pressed with a blender to obtain the juices. An appropriate dilution of the juices or the carbonated beverages was made with deionized water.

The juices or carbonated beverages were diluted in aqueous acetate buffer at $\mathrm{pH} 4.6$. ZVIP $(0.5 \mathrm{~g})$ was added to $100 \mathrm{~mL}$ of the carbohydrate or juice solutions in a vial. After the vial was sealed with a butyl rubber stopper, it was shaken continuously for the duration of the experiment. The mixture was shaken the same way as the standard solutions, and analyzed in the same manner. The samples were diluted in the first step 150 times and prepared according to the protocol presented in Table 2.

Table 2. Protocol of sample preparations for the measurement of fructose after 150-fold dilution. The time of treatment with iron is $10 \mathrm{~min}$

\begin{tabular}{|c|c|c|c|}
\hline \multirow{2}{*}{$\begin{array}{l}\text { Sample } \\
\text { No. }\end{array}$} & \multicolumn{3}{|c|}{ Carbonated beverages } \\
\hline & Sprite® & Caffeine free Pepsi® & Mountain Dew® \\
\hline 1 & $\begin{array}{l}2 \mathrm{~mL} \text { sample }+6 \mathrm{~mL} \text { acetate } \\
\text { buffer }+0.1 \mathrm{~g} \text { iron }\end{array}$ & $\begin{array}{l}2 \mathrm{~mL} \text { sample }+6 \mathrm{~mL} \text { acetate } \\
\text { buffer }+0.1 \mathrm{~g} \text { iron }\end{array}$ & $\begin{array}{l}2 \mathrm{~mL} \text { sample }+6 \mathrm{~mL} \text { acetate } \\
\text { buffer }+0.1 \mathrm{~g} \text { iron }\end{array}$ \\
\hline 2 & $\begin{array}{l}2 \mathrm{~mL} \text { sample }+0.3 \mathrm{~mL} 15-\mathrm{mM} \\
\text { fructose }+5.7 \mathrm{~mL} \text { acetate buffer } \\
+0.1 \mathrm{~g} \text { iron }\end{array}$ & $\begin{array}{l}2 \mathrm{~mL} \text { sample }+0.3 \mathrm{~mL} 15-\mathrm{mM} \\
\text { fructose }+5.7 \mathrm{~mL} \text { acetate buffer } \\
+0.1 \mathrm{~g} \text { iron }\end{array}$ & $\begin{array}{l}2 \mathrm{~mL} \text { sample }+0.3 \mathrm{~mL} 15-\mathrm{mM} \\
\text { fructose }+5.7 \mathrm{~mL} \text { acetate buffer } \\
+0.1 \mathrm{~g} \text { iron }\end{array}$ \\
\hline 3 & $\begin{array}{l}2 \mathrm{~mL} \text { sample }+0.5 \mathrm{~mL} 15-\mathrm{mM} \\
\text { fructose }+5.5 \mathrm{~mL} \text { acetate buffer } \\
+0.1 \mathrm{~g} \text { iron }\end{array}$ & $\begin{array}{l}2 \mathrm{~mL} \text { sample }+0.5 \mathrm{~mL} 15-\mathrm{mM} \\
\text { fructose }+5.5 \mathrm{~mL} \text { acetate buffer } \\
+0.1 \mathrm{~g} \text { iron }\end{array}$ & $\begin{array}{l}2 \mathrm{~mL} \text { sample }+0.5 \mathrm{~mL} 15-\mathrm{mM} \\
\text { fructose }+5.5 \mathrm{~mL} \text { acetate buffer } \\
+0.1 \mathrm{~g} \text { iron }\end{array}$ \\
\hline 4 & $\begin{array}{l}2 \mathrm{~mL} \text { sample }+1 \mathrm{~mL} 15-\mathrm{mM} \\
\text { fructose }+5 \mathrm{~mL} \text { acetate buffer }+ \\
0.1 \mathrm{~g} \text { iron }\end{array}$ & $\begin{array}{l}2 \mathrm{~mL} \text { sample }+1 \mathrm{~mL} 15-\mathrm{mM} \\
\text { fructose }+5 \mathrm{~mL} \text { of acetate } \\
\text { buffer }+0.1 \mathrm{~g} \text { iron }\end{array}$ & $\begin{array}{l}2 \mathrm{~mL} \text { sample }+1 \mathrm{~mL} \\
15 \text { - } \mathrm{mM} \text { fructose }+5 \mathrm{~mL} \\
\text { acetate buffer }+0.1 \mathrm{~g} \text { iron }\end{array}$ \\
\hline
\end{tabular}

\subsection{Validation of the Method}

The proposed method has been validated according to International Conference on Harmonization guidelines (Shabir 2003) and ICH (Conference on Harmonization guidelines) for validation of analytical procedures which include limit of detection, limit of quantitation, linearity, repeatability and intermediate precision, recovery, specificity, and accuracy.

\subsubsection{Limit of detection and limit of quantitation}

The limit of detection (LOD) and limit of quantitation (LOQ) of the developed method were determined by analyzing progressively low concentration of the carbohydrates working solutions $0.01 \mathrm{mM}, 0.01 \mathrm{mM}$ and 0.008 $\mathrm{mM}$ for fructose glucose and sucrose respectively. The LOD is defined as the smallest concentration of the analyte that gives a signal to noise ratio of 3 . The LOQ is the smallest concentration of the analyte that gives a signal to noise ratio of 10 .

\subsubsection{Linearity}

Over the selected concentration range, a linear relationship was obtained between the absorbance intensity and concentration. Linearity was established using five different concentrations: $(0.05,0.1,1.5,2$ and $2.3 \mathrm{mM})$ of carbohydrates working standard solution.

Each concentration level was prepared in five replicates $(n=6)$. Results have shown that this method is linear 
over the range of $0.05 \mathrm{mM}-2.4 \mathrm{mM}$. The linear regression analysis demonstrates an excellent relationship between the fluorescence intensity and concentration of melamine added with correlation coefficients $\left(\mathrm{R}^{2}\right)$ of 0.99 .

\subsubsection{Precision}

The precision of the method was determined by repeatability (intra-day) and intermediate precision (inter-day). Repeatability was evaluated by analyzing five replicates of the standard solution of melamine $(15 \mathrm{mM})$ on the same day. The intermediate precision was determined by comparing the results on different days (4 days). The mean values and standard deviations of absorption measurement are listed in Table 3.

Table 3. Summary of the parameters of the method

\begin{tabular}{llllll}
\hline Carbohydrates & $\lambda_{\operatorname{Max}}{ }^{\mathrm{a}}(\mathrm{nm})$ & $\mathrm{LDR}^{\mathrm{b}}(\mathrm{mM})$ & $\mathrm{R}^{2 \mathrm{c}}$ & $\mathrm{LOD}^{\mathrm{d}}(\mathrm{mM})$ & $\mathrm{RSD}^{\mathrm{e}} \%$ \\
\hline Fructose & 490,630 & $0.05-2.3$ & 0.9912 & 0.01 & 4 \\
Glucose & $451,520,632$ & $0.05-2.5$ & 0.9992 & 0.01 & 4 \\
Sucrose & $490,533,632$ & $0.02-2.5$ & 0.9964 & 0.008 & 5 \\
\hline
\end{tabular}

${ }^{\mathrm{a}}$ Maximum absorption. ${ }^{\mathrm{b}}$ Linear dynamic range ${ }^{\mathrm{c}}$ Correlation coefficient $\left(\mathrm{R}^{2}\right) .{ }^{\mathrm{d}}$ Limit of detection.

${ }^{\mathrm{e}}$ Relative standard deviations for Fructose, Glucose and Sucrose. Number of repetitions (7)

\subsubsection{Recovery}

The recovery of the method was determined by the standard addition method on selected Samples. A known amount of carbohydrate was added to a solution with an initial concentration $\mathrm{C}_{0}(0.42,0.63$ and 0.27 for sucrose, glucose and fructose respectively), at three levels $50 \%, 100 \%$, and $150 \%(\mathrm{n}=5)$. The percentage recovery was calculated according to reference (Rima et al., 1982) and data are presented in Table 4 . The recoveries were found to be $95 ; 93$ and $93 \%$ respectively.

Table 4. Results for concentration determination of artificial mixture of three sugars

\begin{tabular}{llll}
\hline Sugars & \multicolumn{2}{c}{ Concentration $(\mathrm{mM})$} & \% Error \\
\hline & Measured $(\mathrm{Q})$ & Known $(\mathrm{Q})$ & \\
\hline Sucrose & 0.42 & 0.40 & 5 \\
Glucose & 0.63 & 0.59 & 7 \\
Fructose & 0.27 & 0.29 & 7 \\
\hline
\end{tabular}

\subsubsection{Specificity}

Each carbohydrate conducts, after its oxidation by the zero valent iron powder to a specific chromogen and then has a complex with TBA, this can specify each carbohydrate and allows the monitoring according to its concentrations and consequently to its qualitative and quantitative determination.

\section{Results and Discussion}

\subsection{Reaction Nature and Specificity of Zero-valent Iron with Carbohydrates}

According to the Lobry de Bruy and van Ekenstein transformation (Angyal 2001), fructose and glucose can each form an enediol in either an acidic or basic solution (Figure 1). Sucrose upon hydrolysis to glucose and fructose would be expected to give the same enediol structure. In aqueous solution at $\mathrm{pH}$ less than 7, ZVIP and the enediol can undergo hydrogenation and/or hydroxylation reaction similar to those observed by Sweeny (Sweeny et al., 1972; Rima et al., 2006; Corma Canos et al., 2007). Sweeny showed both hydroxylation and saturation in the case of the iron-catalyzed reduction of chlorobenzene, where cyclohexanol is observed as a product. An aldehyde also can be formed during the oxidation of sugar (Breton et al., 2007). The 2-thiobarbituric acid (TBA) test was discovered 50 years ago for the measurement of lipid oxidation. Since then, it has been widely used for the measurement of the oxidative state of biology and food materials. It had been proposed that the products obtained by oxidation present reactive substances with TBA and form characteristic complex. In the case of sucrose, glucose and fructose, the products of the reaction with hydroxyl free radicals derived from iron show visible absorption spectra specific for each of the sugars as shown in Figure 2. The important analytical parameters are presented in Table 3. 


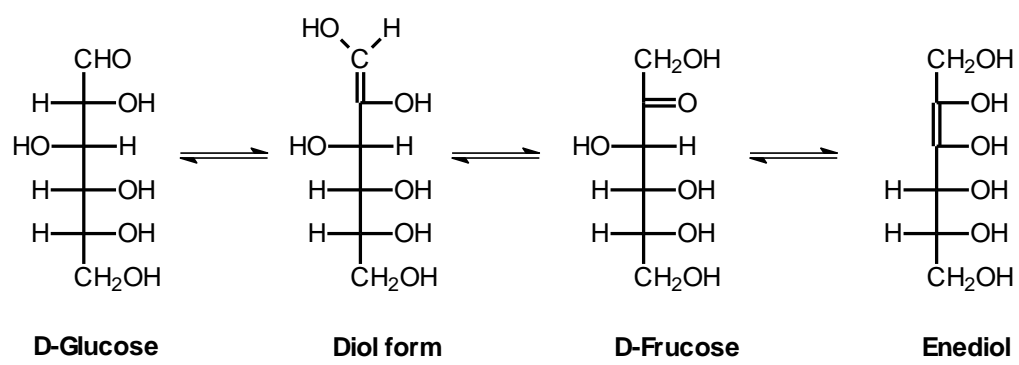

Figure 1. Transformation between glucose, fructose, and their diol and enediol forms

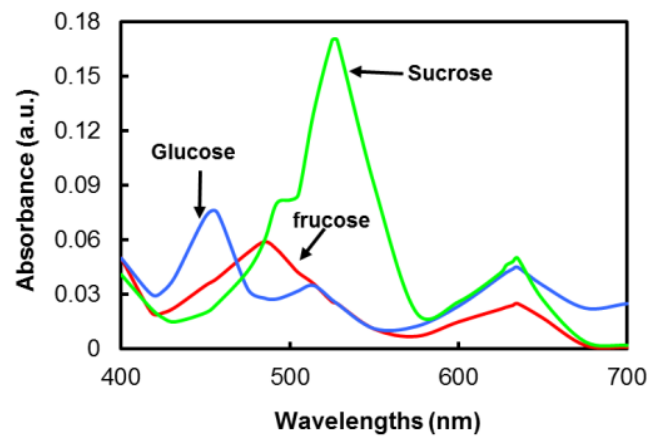

Figure 2. Absorption spectra of fructose, glucose, and sucrose after reaction with iron and formation of a complex with TBA

\subsection{Linearity and Detection Limit}

Absorption linearity and LODs for the three sugars were determined. Fructose was determined from 0.05 to 2.3 $\mathrm{mM}(\mathrm{n}=6)$ with a linear least-squares slope of 0.016 , a y-axis intercept of -1.8 , and a correlation coefficient $\mathrm{R}^{2}$ $=0.9912$. Sucrose was determined from 0.05 to $2.3 \mathrm{mM}(\mathrm{n}=7)$ with a linear least-squares slope of 0.022 a y-axis intercept of -1.74 , and a correlation coefficient $\left(\mathrm{R}^{2}\right)$ of 0.9964 , glucose was determined from 0.02 to $3.5 \mathrm{mM}(\mathrm{n}=$ 8) with a linear least-squares slope of 0.0954 , a y-axis intercept of -0.41 , and a correlation coefficient of $\left(\mathrm{R}^{2}\right)$ $=0.9992$. For the three linearity plots, at least points run in triplicate. The relative standard deviations (RSD) for fructose, glucose and sucrose, ranged from $4 \%$ to $5 \%$. LODs were $0.01,0.01$, and $0.008 \mathrm{M}$ respectively.

\subsection{Quantitative Analysis of Sugars in Mixtures}

The samples that were fortified with sucrose, fructose and glucose were used to determine quantitative analysis when sucrose was considered the internal standard and glucose was the target analyte. The use of an internal standard increase measurement accuracy. In the case of measurements other than glucose, we proceeded to change the internal standard and the unknown compound to be measured. Figure 2 shows the absorption spectra of sucrose, fructose, and glucose. Figure 3 presents the absorption spectra of a mixture of sucrose, glucose and fructose after treatment with iron and TBA. The extrapolation (Figure 4) was performed from the regression curve $\mathrm{A}^{*}=\mathrm{CQ}^{*}+\mathrm{D}$ representing the function $\mathrm{A}^{*}=\left(\mathrm{A}^{*}{ }_{\mathrm{o}} / \mathrm{Q}_{\mathrm{o}}\right) \mathrm{Q}+\mathrm{A}^{*}{ }_{\mathrm{o}}$ where $\mathrm{A}^{*}$ is the normalized absorption intensity equal to the ratio of the solute absorption signal over the internal standard absorption signal. $\mathrm{Q}_{0}$ is the solute concentration to be measured. $\mathrm{A}^{*}{ }_{\mathrm{o}}$ is the normalized absorption intensity of the start solution. $\mathrm{Q}$ is the known concentration added and $\mathrm{Q}_{0}$ is determined by the negative intercept of the curve with abscissa axis (Rima et al., 1982). Experimental data were found to be less than 10\% error (Table 4) as compared with the actual concentrations of sugars. 


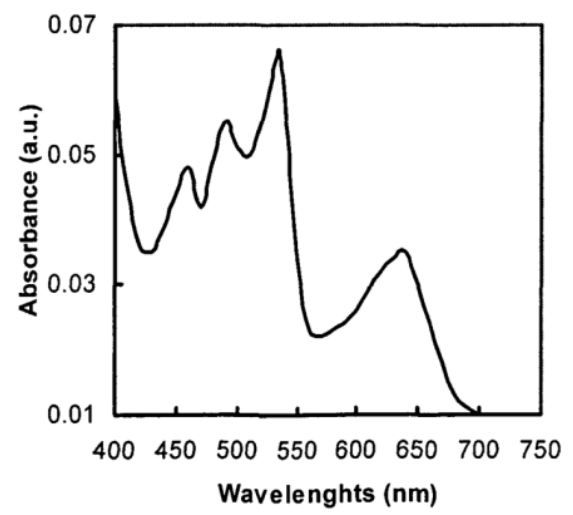

Figure 3. Absorption spectrum of a mixture of fructose, glucose and sucrose (1:1:1 in weight) after reaction with iron and formation of a complex with TBA

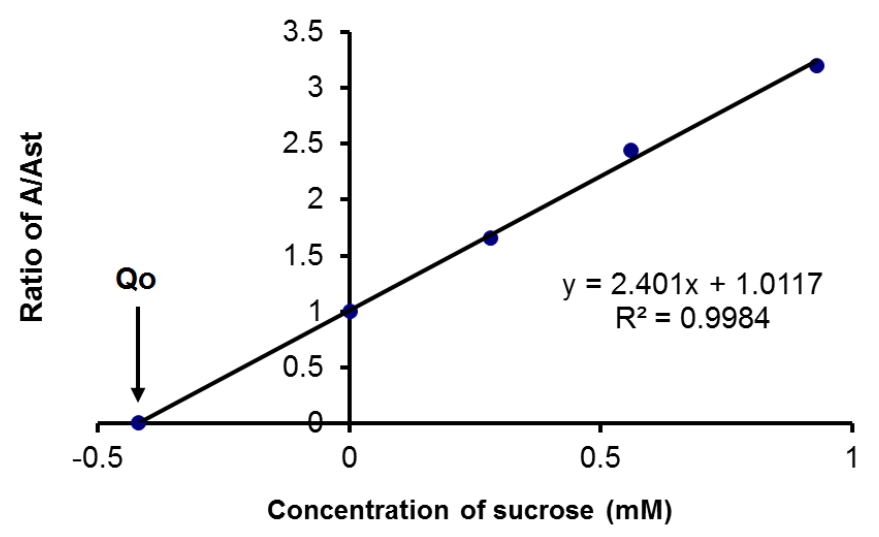

Figure 4. Calibration curve of sucrose in a mixture of fructose, glucose and sucrose. Internal standard method

\subsection{Determination of Fructose in Carbonated Beverages}

The interest was to determine the concentrations of fructose in real samples such as carbonated beverages that contain high-fructose corn syrup. The composition of high-fructose corn syrup is about $55 \%$ fructose, $41 \%$ glucose, and $4 \%$ of other saccharides. The presence of ascorbic acid (vitamin C) and caffeine do not interfere with the measurements because their absorption spectra are completely separated. Fructose, glucose, and sucrose can be determined selectively using the characteristic absorption maximum of each sugar when complexed with TBA. After the analysis by the standard addition method, the average recoveries of measured values of fructose in comparison with the labeled value were $100 \%$ for Sprite $(n=5), 99 \%$ for caffeine-free Pepsi $(n=5)$, and $98 \%$ for Mountain Dew $(\mathrm{n}=5)$.

\section{Conclusion}

Carbohydrates such as fructose, glucose and sucrose do not have adequate chromogen or fluorophore, which eliminates direct detection by standard UV / VIS spectrometry or fluorescence. Most carbohydrates absorb light in the near-UV range $(180-200 \mathrm{~nm})$, but interference from other components in the sample prevents direct measurement of absorbance. The reaction between iron and carbohydrates leads to the fragmentation of sugars followed by complexation with absorbent chromophore in the visible, offers the possibility of determination of three sugars separately or in mixture. The results of this study demonstrate a simple and rapid concept for the identification and analysis of fructose, glucose and sucrose. However, further work is needed to extend the method of analysis to other oligosaccharides, currently underway in our laboratory.

This new method can provide quick, simple, economical and accurate determinations of carbohydrate type and concentration for a number of applications, but not limited to:

-Identity standards: food must be of a composition that complies with government regulations; 
- Nutrition Labeling: inform consumers of the nutritional content of foods;

-Failure detection: each type of food has a carbohydrate "fingerprint";

- Food quality: the physicochemical properties of foods, such as smoothness, appearance, stability and texture, depend on the type and concentration of carbohydrates present.

-Control of the quality of products containing sugar: Food manufacturers must control the quality of their products for the content of their ingredients;

-Food processing: The effectiveness of many food processing operations depends on the type and concentration of carbohydrates present.

In summary, this new method is fast, simple and economical for measuring carbohydrates in foods, fruit juices, etc. It meets the needs of producers, consumers, regulators, official authorities, research laboratories and industries.

\section{Ethical approval}

This article does not contain any studies with human participants or animals performed by any of the authors.

\section{Acknowledgement}

This work was funded by Lebanese University.

\section{References}

Alfaro, G., Meurens, M., \& Birth, G. S. (1990). Liquid analysis by dry-extract near-infrared reflectance on fiberglass. Appl Spectrosc, 44, 979-986. https://doi.org/10.1366/0003702904086687

Angyal, S. J. (2001). The Lobry de Bruyn-Alberda Van Ekenstein Transformation and Related Reactions. Glycosci Epimerisation, Isomerisation Rearrange React Carbohydrates, 215, 1-14. https://doi.org/10.1007/3-540-44422-X_1

Arias, V., Castells, R., \& Malacalza, N. (2003). Determination of oligosaccharide patterns in honey by solid-phase extraction and high-performance liquid chromatography. Chromatographia, 58, 797-801.

Breton, T., Bashiardes, G., Leger, J. M., \& Kokoh, K. B. (2007). Selective oxidation of unprotected carbohydrates to aldehyde analogues by using TEMPO salts. European J Org Chem, 1567-1570. https://doi.org/10.1002/ejoc.200600914

Corma, C. A., Iborra, S., \& Velty, A. (2007). Chemical routes for the transformation of biomass into chemicals. Chem Rev., 107, 2411-2502. https://doi.org/10.1021/cr050989d

Danielson, N. D., Heenan, C. A., Haddadian, F., \& Numan, A. Q. (1999). Fluorometric determination of fructose, glucose, and sucrose using zirconyl chloride. Microchem J., 63, 405-414. https://doi.org/10.1006/mchj.1999.1802

Giangiacomo, R., \& Dull, G G. (1986). Near Infrared Spectrophotometric Determination of Individual Sugars in Aqueous Mixtures. J Food Sci., 51, 679-683. https://doi.org/10.1111/j.1365-2621.1986.tb13910.x

Lanza, E., \& Li, B. W. (1984). Application of near infrared spectroscopy for predicting the sugar content of fruit juices. J Food Sci., 49, 995-998. https://doi.org/10.1111/j.1365-2621.1984.tb10378.x

Li, W., Goovaerts, P., \& Meurens, M. (1996). Quantitative Analysis of Individual Sugars and Acids in Orange Juices by Near-Infrared Spectroscopy of Dry Extract. J Agric Food Chem., 44, 2252-2259. https://doi.org/10.1021/jf9500750

Matsumoto, K., Matsubara, H., Hamada, M., Ukeda, H., \& Osajima, Y. (1990). Simultaneous determination of glucose, ethanol and lactate in alcoholic beverages and serum by amperometric flow injection analysis with immobilized enzyme reactors. J Biotechnol., 14, 115-126. https://doi.org/10.1016/0168-1656(90)90023-5

McClure, F. W. (1994). The Giant is Running Strong. Anal Chem., 66, 43-53. https://doi.org/10.1021/ac00073a002

Rima, J., Lamotte, M., \& Joussot-Dubien, J. (1982). Application of the Shpol'skii Effect to Quantitative Analysis of Momomethylphenanthrene Isomers. Anal Chem., 54, 1059-1064. https://doi.org/10.1021/ac00244a011

Rima, J., Li, Q. X., \& Aouezova, L. (2006). Generation of free radicals, analytical methods, bacterial disinfection, and oxidative destruction of organic chemicals using zero valent iron and other metals. PCT Int Appl., 67.

Schmilovitch, Z., Mizrach, A., Hoffman, A., et al (2000) Determination of mango physiological indices by 
near-infrared spectrometry. Postharvest Biol Technol., 19, 245-252.

https://doi.org/10.1016/j.foodcont.2015.04.019

Schmutzler, M., Beganovic, A., Böhler, G., \& Huck, C. W. (2015). Methods for detection of pork adulteration in veal product based on FT-NIR spectroscopy for laboratory, industrial and on-site analysis. Food Control., $57,258-267$.

Shabir, G. A. (2003). Validation of high-performance liquid chromatography methods for pharmaceutical analysis - Understanding the differences and similarities between validation requirements of the US Food and Drug Administration, the US Pharmacopeia and the International Con. J Chromatogr A., 987, 57-66. https://doi.org/10.1016/S0021-9673(02)01536-4

Stober, P., Lamoureux, T., Martin, G. G., et al (1998) Standardisation of the detection of invert sugar addition to apple juice by capillary gas chromatography. Zeitschrift Fur Leb Und-forsch a-Food Res Technol., 207, 332-339.

Suhandy, D., Suzuki, T., Ogawa, Y., Kondo, N., Naito, H., Ishihara, T., Takemoto, Y., \& Liu, W. J. (2012). A Quantitative Study for Determination of Glucose Concentration Using Attenuated Total Reflectance Terahertz (ATR-THz) Spectroscopy. Eng Agric Environ Food, 5(3), 90-95. https://doi.org/10.1016/S1881-8366(12)80020-6

Sweeny, K. H., Covina, W., \& Fisher, J. R. (1972). Reductive Degradation of Halogenated Pesticides. 210, 1-6

Trifirò, A., Saccani, G., Gherardi, S., Vicinia, E., Spottia, E., ... Previdia, M. P. (1997). Use of ion chromatography for monitoring microbial spoilage in the fruit juice industry. $J$ Chromatogr A., 770(1-2), 243-252. https://doi.org/10.1016/S0021-9673(97)00049-6

Vodnar, D., \& Socaciu, C. (2008). Comparative Analysis of Lactic Acid Produced By Apple Substrate Fermentation, Using Hplc and Tectronik Senzytec Biosensor. Bull UASVM, Agric., 65, 1843-5246.

Weiß, K. (2017). Determination of Single Sugars, Including Inulin, in Plants and Feed Materials by High-Performance Liquid Chromatography and Refraction Index Detection. Fermentation, 3, 36. https://doi.org/10.3390/fermentation3030036

Whitesides, G. M. (1984). Methods of Enzymatic Analysis. In: Bergmeyer HU, Bergmeyer J, Grassl M (eds) Metabolites 1: Carbohydrates, 3rd edn. Verlag Chemie, Weinheim 1984, Cambridge USA, pp. 701

Ye, W., Lorimor, J. C., Hurburgh, C. R., Zhang, H., \& Hattey, J. (2005). Application of Near-Infrared Reflectance Spectroscopy for Determination of Nutrient Contents in Liquid and Solid Manures Application of Near-Infrared Reflectance Spectroscopy for Determination. Trans ASAE, 48, 1911-1918. https://doi.org/10.13031/2013.20000

\section{Copyrights}

Copyright for this article is retained by the author(s), with first publication rights granted to the journal.

This is an open-access article distributed under the terms and conditions of the Creative Commons Attribution license (http://creativecommons.org/licenses/by/4.0/). 